\title{
Assessing the ideology of total quality management towards hotel sustainability performance: empirical evidence using structural equation modelling
}

\section{Kit Yeng Sin*}

Faculty of Economics and Business,

Universiti Malaysia Sarawak,

94300 Sarawak, Malaysia

Email: kysin@unimas.my

*Corresponding author

\section{Muhammad Shahar Jusoh}

School of Business Innovation and Technopreneurship,

Univesiti Malaysia Perlis,

01000 Kangar Perlis, Malaysia

Email: shahar@unimap.edu.my

\section{Abbas Mardani}

Department of Marketing,

Muma College of Business,

University of South Florida,

Tampa, FL 33813, USA

Email: abbasmardani@usf.edu

\begin{abstract}
Total quality management (TQM) practices are one of the remarkable management initiatives adopted by the hotel industry to conserve the environment and ameliorate the quality of life while executing activities. Due to the existence of the value creation notion, economic value is no longer the only prerequisite assessing hotel sustainability performance, environmental and social aspects should also be considered when evaluating sustainability performance. The purpose of this study is to investigate the relationship between TQM practices and sustainability performance, taking into account the environmental, economic and social aspects. A questionnaire survey is conducted among 238 hotels with ISO 9001 certification in Malaysia. Structural equation modelling is employed to assess the relationship between TQM practices and sustainability performance. The findings of this study reveal that employee management has the most significant impact on sustainability performance. Hence, it is posited that the hotels in Malaysia are extremely concentrated on employee engagement in the implementation of TQM practices to accomplish sustainability objective.
\end{abstract}

Keywords: total quality management; TQM; sustainability performance; economic performance; social performance; environmental performance; structural equation modelling; SEM. 